\title{
Antibacterial activity of propolis-based toothpastes for endodontic treatment
}

\author{
Fausto Rodrigo Victorino ${ }^{1 *}$, Clovis Monteiro Bramante ${ }^{1}$ Evandro Watanabe $^{2}$, Izabel Yoko Ito $^{3}$, \\ Selma Luci Franco ${ }^{4}$, Mirian Marubayashi Hidalgo ${ }^{5}$
}

\begin{abstract}
${ }^{1}$ Department of Endodontics, Faculty of Dentistry of Bauru, University of São Paulo, ${ }^{2}$ Department of Basic Sciences, Federal University of Jequitinhonha and Mucuri Valleys, ${ }^{3}$ Department of Clinical, Toxicological, and Bromatological Analyzes, Faculty of Pharmaceutical Sciences of Ribeirão Preto, University of São Paulo, ${ }^{4}$ Department of Pharmacy and Pharmacology, State University of Maringá, ${ }^{5}$ Department of Dentistry (Endodontics), State University of Maringá.
\end{abstract}

\begin{abstract}
This study evaluated the antibacterial activity of propolis-based toothpastes used as intracanal medication in endodontic treatment. The propolis-based toothpastes were prepared using an extract established in previous studies (identified as A70D and D70D). Calcium hydroxide paste was used as a control. The bacteria employed were Streptococcus mutans (ATCC 25175), Staphylococcus aureus (ATCC 6538), Staphylococcus aureus (ATCC 25923), Kocuria rhizophila (ATCC 9341), Escherichia coli (ATCC 10538), Pseudomonas aeruginosa (ATCC 27853), Enterococcus hirae (ATCC 10541), Streptococcus mutans (ATCC 25175). Five field strains isolated from saliva were used: Staphylococcus spp. (23.1 - coagulase positive), Staphylococcus spp. (23.5 - coagulase negative), Staphylococcus spp. (26.1 coagulase positive), Staphylococcus spp. (26.5 - coagulase negative) and Staphylococcus epidermidis (6epi). The diffusion-well method on double-layer agar was used in a culture medium of Tryptic Soy Agar. The plates were kept at room temperature for two hours to allow the diffusion of pastes in the culture medium, and then incubated at $35^{\circ} \mathrm{C}$ for twenty-four hours in aerobiosis and in microaerophilia (S. mutans). After this period, the total diameter of the inhibition halo was measured. The results were analyzed by ANOVA analysis of variance, followed by the Tukey test at $p<0.05$. The propolis-based toothpastes presented antibacterial activity against $83.3 \%$ of the analyzed bacteria. For $66.7 \%$ of these bacteria, the propolis-based toothpastes exhibited greater antibacterial activity than calcium hydroxide. The present results allow us to conclude that the experimental pastes A70D and D70D showed good activity against aerobic bacteria, proving more effective than calcium hydroxide.
\end{abstract}

Uniterms: Propolis/antibacterial activity. Tooth paste/with propolis/antibacterial activity. Endodontics/ treatment.

O objetivo deste estudo foi avaliar a atividade antibacteriana de formas farmacêuticas a base de própolis para uso no tratamento endodôntico como medicação intracanal. As formulações de própolis, em forma de pastas, foram preparadas a partir de um extrato pré-estabelecido em estudos anteriores e identificadas como A70D e D70D. Como controle, foi utilizado pasta de hidróxido de cálcio. As bactérias utilizadas foram: Streptococcus mutans (ATCC 25175), Staphylococcus aureus (ATCC 6538), Staphylococcus aureus (ATCC 25923), Kocuria rhizophila (ATCC 9341), Escherichia coli (ATCC 10538), Pseudomonas aeruginosa (ATCC 27853), Enterococcus hirae (ATCC 10541), Streptococcus mutans (ATCC 25175) e 5 cepas de campo isoladas da saliva: Staphylococcus spp. (23.1 - coagulase positiva), Staphylococcus spp. (23.5 - coagulase negativa), Staphylococcus spp. (26.1 - coagulase positiva), Staphylococcus spp. (26.5 - coagulase negativa) e Staphylococcus epidermidis (6epi). Foi utilizado o método poço difusão em camada dupla de ágar, em meio de cultura Tryptic Soy Agar. As placas foram mantidas à temperatura ambiente por $2 \mathrm{~h}$ para permitir a difusão das pastas no meio de cultura, e então incubadas a $35^{\circ} \mathrm{C}$ por $24 \mathrm{~h}$ em aerobiose e em microaerofilia (S. mutans). Após este período, foi medido o diâmetro total do halo de inibição. Os resultados foram submetidos ao teste de análise de variância ANOVA seguido do teste de Tukey com $\mathrm{p}<0,05$. As pastas a base de própolis apresentaram atividade antibacteriana contra 83,3\% das bactérias analisadas. Para $66,7 \%$ das bactérias, as pastas de própolis apresentaram maior atividade

*Correspondence: F. R. Victorino. Departamento de Endodontia, Faculdade de Odontologia de Bauru - USP, Al. Dr. Octavio Pinheiro Brizola, 9-75, 17012-901 - Bauru-SP, Brasil. E-mail: frvictorino@ig.com.br. 
antibacteriana que o hidróxido de cálcio, e este foi mais efetivo apenas para Streptococcus mutans (ATCC 25175), Staphylococcus aureus (ATCC 25923) e Pseudomonas aeruginosa (ATCC 27853). De acordo com a metodologia utilizada, pode-se concluir que as pastas experimentais A70D e D70D apresentam boa atividade contra bactérias aeróbias, sendo superior ao hidróxido de cálcio.

Unitermos: Própolis/atvidade antibacteriana. Pasta de dente/com própolis/atividade antibacteriana. Endodontia/tratamento.

\section{INTRODUCTION}

Intracanal medication helps in the fight against root canal system infection, and can also stimulate the repair process of apical tissues. To achieve this, it must eliminate the bacteria and fungi surviving in biomechanical preparation, act as a physicochemical barrier against reinfection by mouth microorganisms, and decrease peri-radicular inflammation.

Propolis, a substance produced by bees for protection of the hive against microorganisms (Trevisan, 1983), has been widely used in popular medicine. In the scientific community, propolis has demonstrated antibacterial (Wuyuan, Green, Birch , 1990; Grange, Davey, 1990; Santos et al., 2002; Koru et al., 2007), antifungal (Kujumgiev et al., 1999; Quintero-Mora et al., 2008), anti-inflammatory (Dobrowolski et al., 1991; Hu et al., 2005; Sosa, 2007), cicatrizant (Perri de Carvalho, Tagliavini, Tagliavini, 1991) and immunomodulator (Dimov et al., 1992; Simões et al., 2004) action.

Few studies have associated propolis and its antiinflammatory and antibacterial effects with endodontic treatment, such as those by Heys (1980), Matos (1989) and Sabir et al. (2005). Perhaps this is due to the intrinsic difficulty of introducing propolis and removing it from the internal side of the root canal.

Therefore, the purpose of this study was to evaluate the antibacterial activity of propolis-based pharmaceutical forms for use in endodontic treatment as intracanal medication.

\section{MATERIAL AND METHODS}

The propolis-based formulas were prepared from a brown extract (called PPE1) predefined in previous studies (Victorino et al., 2007), which was collected in the Northeastern state of Paraná, Brazil. The solvent used in the formulas was an ethylic alcohol based solution. The formulas, in the form of toothpastes, were labeled A70D and D70D. P.A. calcium hydroxide prepared with propylene glycol was used as a control formula.

Twelve bacteria were used in the study [eleven aerobic and one facultative anaerobic - Streptococcus mutans
(ATCC 25175)], seven of which were standard strains: Staphylococcus aureus (ATCC 6538), Staphylococcus aureus (ATCC 25923), Kocuria rhizophila (ATCC 9341), Escherichia coli (ATCC 10538), Pseudomonas aeruginosa (ATCC 27853), Enterococcus hirae (ATCC 10541) and Streptococcus mutans (ATCC 25175) and five, community field strains isolated from saliva: Staphylococcus spp. (23.1 - coagulase positive), Staphylococcus spp. (23.5 - coagulase negative), Staphylococcus spp. (26.1 - coagulase positive), Staphylococcus spp. (26.5 - coagulase negative) and Staphylococcus epidermidis (6epi).

The technique employed to evaluate the toothpastes' antibacterial activity was that of diffusion on double-layer Agar, described by Grove, Randall (1955), which was performed in quadruplicate. The culture medium Tryptic Soy Agar (Difco ${ }^{\mathrm{TM}}$, USA) was distributed in petri dishes $(20 \times 100 \mathrm{~mm})$ sterilized to form a base-layer of $12.0 \mathrm{~mL}$. After medium solidification, $8.0 \mathrm{ml}$ of Tryptic Soy Agar containing $1 \%$ of bacterial inoculation (at half-scale concentration proposed by McFarland), were spread over the base-layer to form a seed layer (seeding). Subsequently, six 5.0mm-wide wells were made in each Petri dish. The A70D, D70D and calcium hydroxide toothpastes were placed within the wells using sterilized metallic spatulas.

The dishes were pre-incubated at room temperature $\left(25^{\circ} \mathrm{C}\right)$ for two hours to allow diffusion of the toothpastes by the culture medium, and then incubated at $35^{\circ} \mathrm{C}$ for twenty-four hours in aerobiosis (S. aureus, Staphylococcus spp., K. rhizophila, E .coli, P. aeruginosa, E. hirae), or in microaerophilia using the candle jar method (S. mutans). After this period, the total inhibition zone diameter was measured with a millimeter ruler, without deducting the diameter of the well. The results were submitted to ANOVA analysis of variance, followed by the Tukey test at $\mathrm{p}<0.05$.

\section{RESULTS}

The inhibition zone of test and calcium hydroxide toothpastes, as well as the arithmetic mean of respective antibacterial activities (in quadruple), are expressed in Figure 1 and Table I, respectively. The propolis-based toothpastes demonstrated antibacterial activity in ten out 
TABLE I - Susceptibility test of pathogenic microorganisms to propolis-based toothpastes for use in endodontics. Mean inhibition zone $(\mathrm{mm}) *$

\begin{tabular}{lccc}
\hline & A70D & D70D & $\mathrm{Ca}(\mathrm{OH})_{2}$ \\
\hline Staphylococcus aureus (ATCC 6538) & 19.8 & 19.8 & 16.3 \\
Staphylococcus aureus (ATCC 25923) & 20.3 & 20.8 & 25.5 \\
Staphylococcus spp. (23.1 - coagulase positive)** & 20.5 & 20.5 & 14.8 \\
Staphylococcus spp. (23.5 - coagulase negative)** & 25.8 & 24.5 & 20.3 \\
Staphylococcus spp. (26.1 - coagulase positive)** & 17.3 & 16.8 & 12.0 \\
Staphylococcus spp. (26.5 - coagulase negative)** & 20.5 & 20.5 & 16.8 \\
Staphylococcus epidermidis (6epi)** & 20.0 & 20.0 & 13.5 \\
Kocuria rhizophila (ATCC 9341) & 28.8 & 28.0 & 22.8 \\
Escherichia coli (ATCC 10538) & 13.0 & 13.0 & 11.5 \\
Streptococcus mutans (ATCC 25175) & 6.3 & 7.0 & 20.8 \\
Pseudomonas aeruginosa (ATCC 27853) & 0 & 0 & 11.8 \\
Enterococcus hirae (ATCC 10541) & 0 & 0 & 0 \\
\hline
\end{tabular}

* tests in quadruple. ${ }^{* *}$ community field strain (saliva)

of twelve analyzed bacteria $(83.3 \%)$, with the exception of P. aeruginosa (ATCC 27853) and E. hirae (ATCC 10541), which showed resistance even to calcium hydroxide.

For the calcium hydroxide paste, the mean inhibition zone ranged from zero to $25.5 \mathrm{~mm}$, while the propolisbased toothpastes this ranged from zero to $28.0 \mathrm{~mm}$. For eight out of the twelve bacteria (66.7\%), the propolisbased toothpastes presented higher antibacterial activity

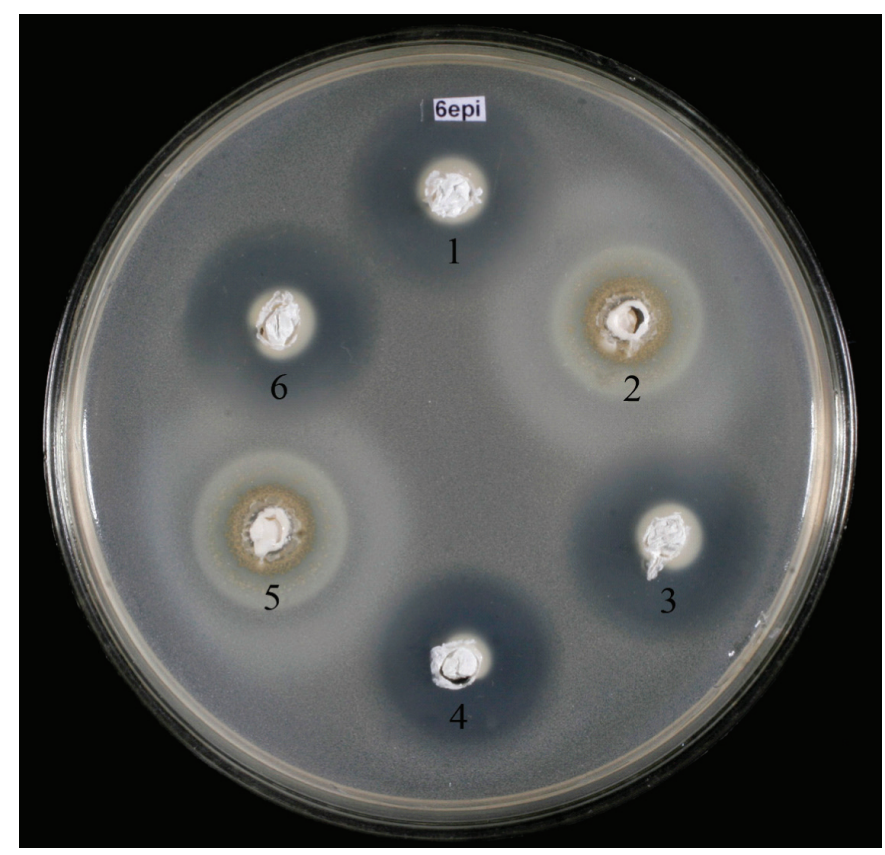

FIGURE 1 - Inhibition zones for S. epidermidis. 1: Paste A70D, 2: $\mathrm{Ca}(\mathrm{OH})_{2}$, 3: Paste D70D, 4: Paste A70D, 5: $\mathrm{Ca}(\mathrm{OH})_{2}$, 6: Paste D70D. than calcium hydroxide, while the latter was more effective against $S$. mutans (ATCC 25175), S. aureus (ATCC 25923) and $P$. aeruginosa (ATCC 27853). The improved results found for propolis-based toothpastes over calcium hydroxide were statistically significant, according to ANOVA, followed by Tukey test $(\mathrm{p}<0.05)$.

\section{DISCUSSION}

This study is part of a line of research line pursuing the development of intracanal medication, in which propolis is the main component. Perhaps, this study may serve to explain why previous microbiologic studies have employed propolis in its raw form, or as an extract. Since this extract presents a resinous quality, it does not represent a good option because the medication must be introduced directly into root canals, making its removal extremely difficult. The development of a paste formula with aqueous components, containing the minimal quantity of propolis extract to maintain its biological activities, would render this therapeutic option viable.

Among the substances employed as intracanal medication, calcium hydroxide has been the most widely used and recommended given its biological properties and antimicrobial action (Sathorn, Parashos, Messer, 2007.). Its high $\mathrm{pH}$ (around 12.5, resulting from the release of hydroxyl ions) exerts a deleterious effect over the bacterial cells as it damages their respective cellular membranes (Freeman, Crapo, 1982), denatures their proteins (Siqueira, Uzeda, 1997), and alters their DNA (Imlay, Linn, 1988). 
The antimicrobial property of propolis has been attributed mainly to flavonoids (Greenaway, Scaysbrook, Whatley, 1990; Viuda-Martos et al. 2008). However, Kujumgiev et al. (1999) have shown that propolis antimicrobial activity results from the synergy between its own components. In this study, the authors have analyzed both the chemical composition and antimicrobial activity from extracts collected in different world regions, including tropical as well as temperate areas. All of these extracts have demonstrated antimicrobial activity, albeit with different chemical characteristics. This result has also been observed by Miorin et al. (2003), who analyzed chemical and microbiological extracts from different regions of Brazil.

Many studies have examined propolis antimicrobial activity using serial dilution tests (Sonmez et al., 2005; Victorino et al., 2007) and diffusion tests on agar (Kujumgiev et al., 1999; Somnes et al,. 2005; Bruschi et al. 2006).

Studies of European propolis employing diffusion test on agar have found diverse results. Metzner et al. (1979) found no diffusion zones, probably due to low diffusion of propolis components through agar. Brumfitt et al. (1990) achieved inhibition zones of $13.0 \mathrm{~mm}$ for $S$. aureus and $S$. epidermidis, but no activity against Streptococcus spp. Dobrowolsky et al. (1991) however, observed inhibition zones of $16.0 \mathrm{~mm}$ for both S. aureus and for Streptococcus pyogenes. Boyanova et al. 2006 used the same methodology to evaluate antimicrobial activity of Bulgarian propolis against anaerobic Gram-positive and Gram-negative bacteria, and recorded inhibition zones greater than or equal to $15 \mathrm{~mm}$ for the majority of Gram-positive bacteria, at concentrations of $30 \mu \mathrm{L}$ of propolis per well.

In the present study, growth inhibition zones were observed for the majority of analyzed bacteria, demonstrating that both propolis-based toothpaste and calcium hydroxide toothpaste were able to diffuse and exert their antibacterial activity in the culture medium.

The experimental toothpastes presented similar results, and failed to present activity against $P$. aeruginosa and $E$. hirae. Against the different strains of $S$. aureus, the mean inhibition zone ranged from 16.8 to $25.8 \mathrm{~mm}$, a mean similar or higher than those found by the cited authors. The weak activity against strains of Streptococcus mutans also confirms data found in the literature (Brumfitt et al., 1990; Bruschi et al., 2006; Duarte et al., 2006).

Compared to calcium hydroxide, the propolis-based toothpastes showed slightly better results; the latter having inhibited the growth of $P$. aeruginosa, while performing significantly better against $S$. mutans.

It is important to take into account that, not only have standard strains been utilized, but also field strains of Staphylococcus spp. from patients' saliva, which dental professionals routinely encounter in the clinic.

Although the endodontic microbiota is mixed and contains largely anaerobic bacteria, the presence of residual aerobic bacteria within the root canal system, after seventy-two and ninety-six hours after the chemomechanical preparation, was demonstrated by Leonardo (1965) and Assed et al. (1996). However, since this was a preliminary study, we used aerobic bacteria and a single facultative anaerobic bacterium (S. mutans). Thus, the possible lack of effect in this group of bacteria may be an exclusion or change factor for the formulas.

\section{CONCLUSION}

The results obtained using this methodology allow us to conclude that the experimental propolis-based toothpastes showed good antibacterial activity against the analyzed bacteria, proving more effective than calcium hydroxide-based toothpaste. However, subsequent studies should be conducted to examine different specific anaerobic bacteria that are commonly present in cases of endodontic infections.

\section{REFERENCES}

ASSED, S.; LEONARDO, M.R.; SILVA, L.A.B.; ITO, I.Y. Prevalência de microrganismos em canais radiculares de dentes com necrose pulpar e reação periapical crônica imunofluorescência indireta:efeito do preparo biomecânico e do curativo de demora pela cultura. Rev. Bras. Odont., v. 53, p.24-28, 1996.

BOYANOVA, L.; KOLAROV, R.; GERGOVA, G.; MITOV, I. In vitro activity of Bulgarian propolis against 94 clinical isolates of anaerobic bacteria. Anaerobe., v.12, p.173-177, 2006.

BRUMFIT, W.; HAMILTON, J.M.T.; FRANKLIN, I. Antibiotic activity of natural products: Propolis. Microbios., v.62, p.19-22, 1990.

BRUSCHI, M.L.; LARA, E.H.; MARTINS, C.H.; VINHOLIS, A.H.; CASEMIRO, L.A.; PANZERI, H.; GREMIÃO, M.P. Preparation and antimicrobial activity of gelatin microparticles containing propolis against oral pathogens. Drug Dev. Ind. Pharm., v.32, p.229-238, 2006.

DIMOV, V.; IVANOVSKA, N.; BANKOVA, V.; POPOV, S. Immunomodulatory action of propolis: Prophylatic activity against Gram-negative infections and adjuvant effect of water-soluble derivative. Vacine, v.10, p.817-823, 1992. 
DOBROWOLSKI, J.W.; VOHORA, S.B.; SHARMA, K.; SHAH, S.A.; NAQVI, S.A.H.; DANDIYA, P.C. Antibacterial, antifungal, antiamoebic, antiinflammatory and antipyretic studies on propolis bee products. $J$. Ethnopharmacol., v.35, p.77-82, 1991.

DUARTE, S.; ROSALEN, P.L.; HAYACIBARA, M.F.; CURY, J.A.; BOWEN, W.H.; MARQUIS, R.E.; REHDER, V.L.; SARTORATTO, A.; IKEGAKI, M.; KOO, H. The influence of a novel propolis on mutans streptococci biofilms and caries development in rats. Arch. Oral Biol., v.51, p.15-22, 2006 .

FREEMAN, B.A.; CRAPO, J.D. Biology of disease. Free radicals and tissue injury. Lab. Invest., v.47, p.412-424, 1982.

GRANGE, J.M.; DAVEY, R.W. Antibacterial properties of propolis (bee glue). J. R. Soc. Med., v.83, p.159-160, 1990.

GREENAWAY, W.; SCAYSBROOK, T.; WHATLEY, F.R. The composition and plant origins of propolis. Bee World, v.71, p.107-118, 1990.

GROVE, D.C.; RANDALL, W.A. Assay methods of antibiotics: a laboratory manual. New York: Medical Encyclopedia Inc, 1955. p.80. (Monographs, 2)

HEYS, D. R. Histological considerations of direct pulp capping agents. J. Dent. Res., v.60, p.1371-1379, 1980.

HU, F.; HEPBURN, H.R.; LI, Y.; CHEN, M.; RADLOFF, S.E.; DAYA, S. Effects of ethanol and water extracts of propolis (bee glue) on acute inflammatory animal models. J. Ethnopharmacol., v.14, p.276-283, 2005.

IMLAY, J.A.; LINN, S. DNA damage and oxygen radical toxicity. Science, v.240, p.1302-1309, 1988.

KORU, O.; TOKSOY, F.; ACIKEL, C.H.; TUNCA, Y.M.; BAYSALLAR, M.; USKUDAR GUCLU, A.; AKCA, E.; OZKOK TUYLU, A.; SORKUN, K.; TANYUKSEL, M.; SALIH, B. In vitro antimicrobial activity of propolis samples from different geographical origins against certain oral pathogens. Anaerobe., v.13, p.140-145, 2007.

KUJUMGIEV, A.; TSVETKOVA, I.; SERKEDJIEVA, Y.; BANKOVA, V.; CHRISTOV, R.; POPOV, S. Antibacterial, antifungal and antiviral activity of propolis of different geographic origin. J. Ethnopharmacol., v.64, p.235-240, 1999.
LEONARDO, M.R. Contribuição para o estudo dos efeitos da biomecânica e da medicação tópica na desinfecção dos canais radiculares. Araraquara, 1965. [Tese de Doutorado. Faculdade de Farmácia e Odontologia de Araraquara. UNESP].

MATOS, T.C. Mumificação pulpar pelo emprego da própolis (nota prévia). Revs. Bras. Odont., v.46, p. 44, 1989.

MIORIN, P.L.; LEVY JÚNIOR, N.C.; CUSTODIO, A.R.; BRETZ, W.A.; MARCUCCI, M.C. Antibacterial activity of honey and própolis from Apis mellifera and Tetragonisca angustula against Staphylococcus aureus. J. Appl. Microbiol., v.95, p.913-920, 2003.

METZNER, J.; BEKEMEIER, H.; PAINTZ, M.; SCHNEIDEWIND, E. On the antimicrobial activity of propolis and propolis constituents. Pharmazie., v.34, p.97$102,1979$.

PERRI DE CARVALHO, P.S.; TAGLIAVINI, D.G.; TAGLIAVINI, R.L. Cicatrização cutânea após aplicação tópica de creme de calêndula e da associação de confrei, própolis e mel em feridas infectadas - Estudo clínico e histológico em ratos. Rev. Ciênc. Bioméd., v.12, p.39-50, 1991.

QUINTERO-MORA, M.L.; LONDOÑO-OROZCO, A.; HERNÁNDEZ-HERNÁNDEZ, F.; MANZANOGAYOSSO, P.; LÓPEZ-MARTÍNEZ, R.; SOTOZÁRATE, C.I.; CARRILLO-MIRANDA, L.; PENIERESCARRILLO, G.; GARCIA-TOVAR, C.G.; CRUZSANCHEZ, T.A. Effect of Mexican propolis extracts from Apis mellifera on Candida albicans in vitro growth. Rev. Iberoam. Micol., v.25, p.22-26, 2008.

SABIR, A.; TABBU, C.R.; AGUSTIONO, P.; SOSROSENO, W. Histological analysis of rat dental pulp tissue capped with propolis. J. Oral. Scien., v.47, p.135-138, 2005.

SANTOS, F.A.; BASTOS, E.M.; RODRIGUES, P.H.; DE UZEDA, M.; DE CARVALHO, M.A.; FARIAS LDE M.; MOREIRA, E.S. Susceptibility of Prevotella intermedia/ Prevotella nigrescens (and Porphyromonas gingivalis) to propolis (Bee Glue) and other antimicrobial agents. Anaerobe., v.8, p.9-15, 2002.

SATHORN, C,; PARASHOS, P.; MESSER, H. Antibacterial efficacy of calcium hydroxide intracanal dressing: a systematic review and meta-analysis. Int. Endod. J., v.40, p.2-10, 2007. 
SIMÕES, L.M.C.; GREGÓRIO, L.E.; SILVA FILHO, A.A.; SOUZA, M.L.; AZZOLINI, A.E.C.S.; BASTOS, J.K.; LUCISANO-VALIM, Y.M. Effect of Brazilian green propolis on the production of reactive oxygen species by stimulated neutrophils. J. Ethnopharmacol., v.94, p.59-65, 2004.

SIQUEIRA JR, J.F.; UZEDA, M. Intracanal medications: evaluation of the antibacterial effects of chlorhexidine, metronidazole, and calcium hydroxide associated with three vehicles. J. Endod., v.23, p.167-169, 1997.

SONMEZ, S.; KIRILMAZ, L.; YUCESOY, M.; YUCEL, B.; YILMAZ, B. The effect of bee propolis on oral pathogens and human gingival fibroblasts. J. Ethnopharmacol., v.102, p.371-376, 2005.

SOSA, S.; BORNANCIN, A.; TUBARO, A.; LOGGIA, R.D. Topical antiinflammatory activity of an innovative aqueous formulation of actichelated propolis vs two commercial propolis formulations. Phytother. Res., v.21, p.823-826, 2007.
TREVISAN, M.D.P. Própolis. Inf. Agropec., v.9, p.50-52, 1983.

VICTORINO, F.R.; FRANCO, S.L.; SVIDZINSKI, T.I.E.; AVILA-CAMPOS, M.J.; CUMAN, R.K.N.; HIDALGO, M.M.; BERSANI-AMADO, C.A. Pharmacological evaluation of propolis solutions for endodontic use. Pharm. Biol., v.45, p.721-727, 2007.

VIUDA-MARTOS, M.; RUIZ-NAVAJAS, Y.; FERNÁNDEZLÓPEZ, J.; PÉREZ-ALVAREZ, J.A. Functional properties of honey, propolis, and royal jelly. J Food Sci., v.73, p.117$124,2008$.

WU-YUAN, C.D.; GREEN, L.; BIRCH, W. X. In vitro screening of Chinese medicinal toothpastes: Their effects on growth and plaque formation on mutans streptococci. Caries Res., v. 24, p.198-202, 1990.

Received for publication on $13^{\text {th }}$ November 2008. Accepted for publication on $07^{\text {th }}$ April 2009. 